\title{
Az összetétel és a technológia hatása az EN AW-8006 ötvözet mechanikai tulajdonságaira
}

\section{The Effect of Chemical Composition and Production Technology on the Mechanical Properties of EN AW-8006 Alloy}

\author{
Pázmán Judit, ${ }^{1}$ Fehér Jánosné, ${ }^{2}$ Gonda Viktor, ${ }^{3}$ Verő Balázs ${ }^{4}$ \\ ${ }^{1}$ Dunaújvárosi Egyetem, Müszaki Intézet, Anyagtudományi Tanszék, Dunaújváros, Magyarország, \\ pazman@uniduna.hu \\ ${ }^{2}$ Dunaújvárosi Egyetem, Müszaki Intézet, Anyagtudományi Tanszék, Dunaújváros, Magyarország, \\ feherjanosne@uniduna.hu \\ 3 Óbudai Egyetem, Bánki Donát Gépész és Biztonságtechnikai Mérnöki Kar, Anyag-és Gyártástudományi \\ Intézet, Budapest, Magyarország, gonda.viktor@bgk.uni-obuda.hu \\ ${ }^{4}$ Dunaújvárosi Egyetem, Müszaki Intézet, Anyagtudományi Tanszék, Dunaújváros, Magyarország, \\ verob@uniduna.hu
}

\begin{abstract}
Aluminum alloys EN AW-8006 with three different Fe:Mn ratios were studied. In the experiments, the temperature of the intermediate soft-annealing between the cold rolling processes and the final soft-annealing at the end of the production technology were varied. The processed samples were subjected to tensile testing and hardness measurements. The effect of chemical composition, based on the test results, showed that for samples without intermediate softening, only the increase of iron content has a significant effect on the yield stress, and the change of iron content refined the final grain structure compared to the reference material.
\end{abstract}

Keywords: $E N A W-8006$, chemical composition, intermediate annealing, tensile test.

\section{Összefoglalás}

Három különböző Fe/Mn arányú EN AW-8006 ötvözetet vizsgáltunk. A gyártástechnológiai műveletsorban a hidegalakítások között végzett közbenső lágyítás és a gyártás végső műveleteként végzett lágyítás hőmérsékletét változtattuk. Az így kapott mintákon szakítóvizsgálatot és keménységmérést végeztünk. A vizsgálati eredmények alapján a kémiai összetétel hatását elemezve arra a következtetésre jutottunk, hogy csak a folyáshatárra van a vastartalom növelésének kismértékü hatása a közbenső lágyítás nélküli minták esetén, valamint a vastartalom változtatása a végső műveletben lágyított termék szemcseszerkezetét finomította a referenciaanyagéhoz képest.

Kulcsszavak: EN AW-8006, kémiai összetétel, közbensö lágyítás, szakítóvizsgálat.

\section{Bevezetés}

Az alumíniumötvözetek 8xxx kategóriája az alumínium speciális ötvözeteit tartalmazza. A legfontosabb típusai az EN AW-8006, (Al-Fe-Mn ötvözet), az EN AW-8011A (Al-Fe-Si) és az EN AW8018 (Al-Fe-Si-Cu) [1]. Ha a Hume-Rothery-szabály feltételeit áttekintjük a korlátlan oldhatóság- ra vonatkozóan, akkor tisztán kitűnik, hogy ezek az ötvözőelemek nem vagy csak korlátozottan oldódnak a szilárd alumíniumban. A korlátozott oldhatóság pedig vegyületfázisok képződését indukálja, akár már a kristályosodás első lépéseként. A vas és a mangán mint átmeneti elemek az intermetallikus fázisok képződését segítik elő, 
amelyhez a gyémántrácsú szilícium is csatlakozik. Tehát a 8xxx-es ötvözetekben, a dendritközi terekben intermetallikus fázisok vannak, melyek mennyisége és alakja a kiválasztott termék gyártástechnológiáját és végfelhasználását is erősen meghatározza.

Jelen munkában az EN AW-8006 ötvözettel foglalkozunk oly módon, hogy egyrészt az EN 5733:2007 szabványon belül választottunk ki kémiai összetételeket, valamint a gyártástechnológiát is optimalizáljuk. A kémiai összetételi módosulatok közti különbség a két fő ötvözőelem, a vas és a mangán arányát jelenti, melyek a dendritközi terekben lévő Al-Fe-Mn vegyületek típusát és ezzel együtt annak morfológiáját is meghatározzák. Az Al-Fe-Mn ternér rendszer alumíniumban gazdag sarkánál lévő kétalkotós fázisokat figyelembe véve, $\mathrm{FeAl}_{3}, \mathrm{MnAl}_{6}$ és $\mathrm{AlMn}_{4}$ fázisok képződnek a kristályosodás során. Azonban a mangán a $\mathrm{MnAl}_{6}$-ban helyet cserélhet a vassal, és háromalkotós vegyületet hoz létre, $\mathrm{FeMnAl}_{12} 13 \%$ Fe- és 14\% Mn-tartalommal [2-3]. Ez az úgynevezett (Fe,Mn)Al6 fázis. A fázisok alakját, méretét és szá-

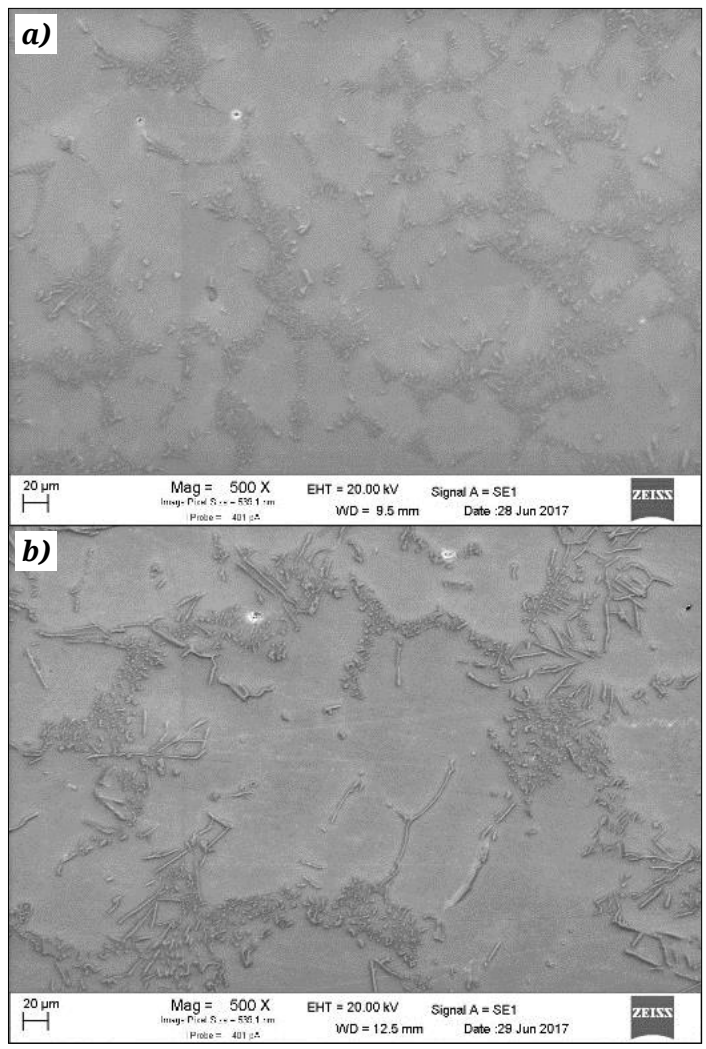

1. ábra. Az EN AW-Al8006 ötvözet mikroszerkezete a) rezet nem tartalmazó EN AW-Al8006 ötvözet; b) rezet tartalmazó $E N A W$-Al8006 ötvözet mát a kristályosodás során a hűlési sebesség, a kémiai összetétel szempontjából a további ötvöző és mikroötvözők jelenléte, a Fe, Mn és Si teljes menynyisége és a szemcsefinomító folyamat is befolyásolja [4]. Az ötvözőelemek közül a réz beépülése az intermetallikus fázis rácsába stabilizálni képes az Al-Fe fázisokra jellemző lemezes szerkezetet (1. ábra), továbbá a nagy hőmérsékletű, hosszú ideig tartó hőkezelés, pl. homogenizálás során megakadályozza a fázisok visszaoldódását, gömbösödését, így megnehezítve a feldolgozási folyamatokat, vagyis a meleg- és a hideghengerlést [5].

A nagyméretű, lemezes szerkezetű fázisok a képlékenyalakítási folyamat során úgynevezett „ceruzafázisok” képződését okozzák, melyek csoportosulása az alakítás során könnyen vezet a késztermék, azaz a kb. $200 \mu \mathrm{m}$ vastag szalag vagy a fólia szakadásához (2-3. ábra) [6].

A szabványon belül maradva, de a kémiai összetételi módosulatok kiválasztásával igyekeztünk a lehető legkedvezőbb fáziseloszlású mikroszer-

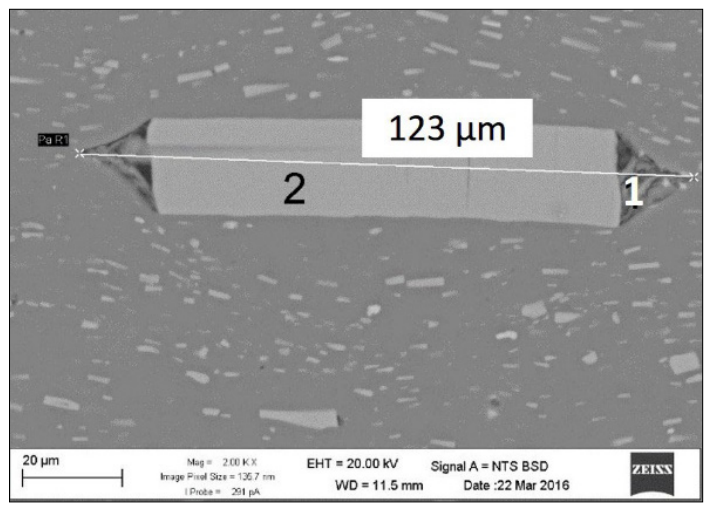

2. ábra. Nagyméretü ceruzafázis az EN AW-8006 ötvözetben. 1 - lyuk a gyantával; 2 - 73,8w\% Al, $19,5 w \% \mathrm{Fe}, 6,7 w \% \mathrm{Mn}$

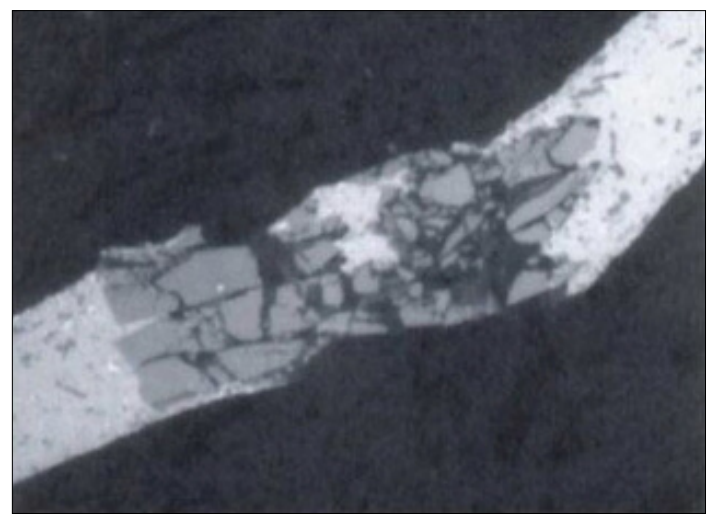

3. ábra. A fólia kettészakadása ceruzafázisok csoportosulása következtében 
kezetet kialakítani, illetve tanulmányoztuk, hogy mely fázisok megjelenése csökkenti a ceruzafázisok síkkitöltési hányadát az alakított ötvözetben.

A 4. ábrán látható, hogy a Fe:Mn arány milyen fázisokat eredményez, és ennek megfelelően alakítottuk ki a kémiai összetételi változatokat.

A kiválasztott kémiai összetételü ötvözeteken homogenizálást, meleghengerlést, hideghengerlést végezve, és a hideghengerlések között a minták egyik felénél közbenső lágyítással, míg a másik felénél közbenső lágyítás nélkül értük el a végtermék végső vastagságát. A technológiai müveletsor utolsó lépése a végtermék lágyítása volt.

\section{Kísérletek, vizsgálatok}

Az ötvözet kémiai összetételének kiválasztásához az EN AW-8006 ötvözet szabványos kémiai összetételét használtuk fel, mely szerint 1,2-2,0\% Fe, max. 0,40\% Si, max. 0,30\% Cu, 0,30-1,0\% Mn, $\max .0,10 \% \mathrm{Mg}$, $\max .0,10 \% \mathrm{Zn}$, a többi $\mathrm{Al}$.

A szakirodalmi megállapítások és előzetes homogenizálási kísérleteink alapján a kémiai öszszetételi variánsok meghatározásához az alábbi alapkoncepciót dolgoztuk ki:

1. A rezet nem tartalmazó EN AW-8006 ötvözetet tekintjük referenciaanyagnak, a továbbiakban az EN AW-8006_R mint referenciaanyag jele szerepel.

2. A szennyezőelemek mennyiségét minimalizáljuk, tehát minél tisztább ötvözetet állítunk elő, hogy így a szennyezőkből képződő szekunder fázisok mennyiségét csökkentsük.

3. Az összetétel-változatok esetén a Fe/Mn arányt változtatjuk, mégpedig a Mn mennyiségének módosítása nélkül, mert ennek az ötvözőelemnek a növelése öntödei problémákat okoz, pl. zagyképződést. Tehát a vas mennyiségét növeljük, illetve csökkentjük. Így a két elem aránya az első esetben, ahol a jelölés R, 3,15, a második esetben (ahol a jelölés csFe = csökkentett vastartalom) 3. A harmadik esetben, ahol a jelölés nFe (növelt vastartalom) 3,875. Az 1. táblázat mutatja az ötvözőelemek mennyiségét.

A kémiai összetétel módosítása mellett a gyártástechnológiai lépéssorban végrehajtott módosításokkal azt vizsgáltuk, hogy a közbenső lágyításnak milyen hatása van a végtermék szemcseszerkezetére és mechanikai tulajdonságaira. A közbenső lágyítást különböző hőmérsékleteken és időtartamokig végeztük el a kiválasztott öszszetételű mintákon, hogy az adott összetételhez a legjobban illő lágyításiparaméter-együttest is meg tudjuk adni. Emellett a végtermékvastagsá-

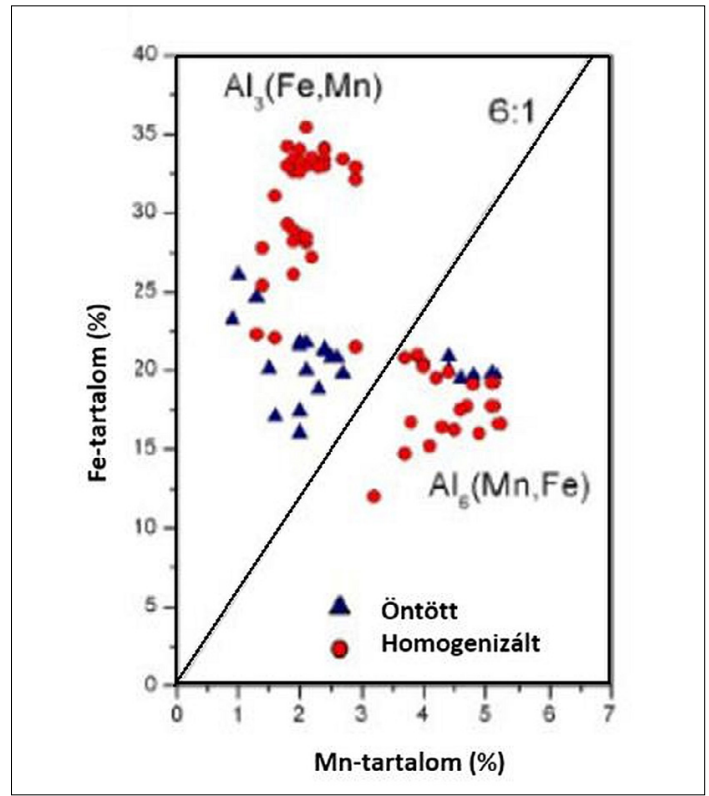

4. ábra. A Fe/Mn arány fázisképző szerepének szemléltetése a Fe és a Mn mennyisége, valamint a gyártási állapot függvényében, EN AW-8006 ötvözetben

1. táblázat. $A z E N A W-8006$ ötvözetváltozatok kémiai összetétele

\begin{tabular}{|l|c|c|}
\hline \multicolumn{1}{|c|}{ Minta neve } & Fe (\%) & Mn (\%) \\
\hline \multirow{2}{*}{ EN AW-8006_R } & 1,05 & 0,3 \\
& 1,15 & 0,4 \\
\hline \multirow{2}{*}{ EN AW-8006_csFe } & 1,15 & 0,3 \\
& 1,25 & 0,4 \\
\hline \multirow{2}{*}{ EN AW-8006_nFe } & 1,3 & 0,3 \\
& 1,5 & 0,4 \\
\hline
\end{tabular}

gon végzett lágyítás hőmérséklet- és időértékeit változtatva kerestük az optimumot erre a technológiai lépésre.

A különböző kémiai összetételű ötvözetekből $50 \mathrm{~mm}$ vastagságú kistuskókat öntettünk le, melyeket $605^{\circ} \mathrm{C}$-on homogenizáltunk, ezt követően $500^{\circ} \mathrm{C}$-on melegen hengereltünk $5,2 \mathrm{~mm}$-es vastagságig, majd a minták egy részét közbenső lágyítás nélkül hidegen hengereltük egészen 0,5 mm végső vastagságig. A minták másik részét pedig a melegalakítást követően hidegen hengereltük $1 \mathrm{~mm}$-es vastagságig, melynek elérésekor a minták megkapták a közbenső lágyítást, és ezt követően fejeztük be a hidegalakítást 0,5 mm-en. A közbenső lágyítás hőmérséklete $1 \mathrm{~mm}$-en: $320^{\circ} \mathrm{C}, 340{ }^{\circ} \mathrm{C}$, $360{ }^{\circ} \mathrm{C}$ és $380^{\circ} \mathrm{C}$ volt. A végső lágyítás hőmérséklete $0,5 \mathrm{~mm}$-en: $220^{\circ} \mathrm{C}, 260{ }^{\circ} \mathrm{C}, 300{ }^{\circ} \mathrm{C}, 340{ }^{\circ} \mathrm{C}$ és 
$380{ }^{\circ} \mathrm{C}$. A lágyítási idő (felhevítés + hőn tartás) minden hőmérsékletnél két órát jelentett. Az így előállított mintákon szakítóvizsgálatot, mikrokeménység-mérést és szövetszerkezet-vizsgálatot végeztünk.

Az 5. ábra mutatja a közbenső lágyítás hatását az ötvözetek keménységértékeire. Azt tapasztaltuk, hogy az ötvözet már $320^{\circ} \mathrm{C}$-on részleges lágyulást mutat, és a keménység a hőmérséklet növelésével már csak kismértékben változik, valamint az összetételi változatok között érdemi különbségek nem mutatkoznak. A teljes kilágyulás $340{ }^{\circ} \mathrm{C}$-on következik be. A közbenső lágyított darabot a végső vastagságig alakítottuk, majd elvégeztük a végső lágyítást.

A 6. ábrán azt látjuk, hogy az ötvözet a kémiai összetételi változatoktól függetlenül már $260^{\circ} \mathrm{C}$-on részlegesen kilágyul, a hőmérséklet növelésével már csak csekély mértékben változik a keménység. A teljes kilágyulás $300{ }^{\circ} \mathrm{C}$-on következik be.

A közbenső lágyítás nélküli mintáknál a végső lágyítást követően a 7. ábra diagramjai mutatják a keménységértékeket.

A 7. ábra diagramjai alapján, ha a technológiai lépéssorból kivesszük a közbenső lágyítást, az ötvözet $300{ }^{\circ} \mathrm{C}$-on fog kilágyulni, hasonlóan, mint a közbenső lágyítással lágyított mintáknál, de a részleges lágyulás mértéke - a keménységmérési adatok alapján - itt lényegesen kisebb, mint a közbensőleg is lágyított mintáknál. A kémiai összetételi változatok között itt sem fedezhető fel érdemi különbség.

A szakítóvizsgálat eredményeit áttekintve (8. ábra) az egyezményes folyáshatárértékeknél a közbenső lágyítás nélküli mintákon nagyobb értékeket mértünk, ami az alakított állapotból adódik. A kémiai összetételi változatokat figyelembe véve a növelt vastartalmú ötvözet nagyobb értéket mutat, míg a másik két összetétel közel azonosat. A szakítószilárdság és a százalékos szakadási megnyúlás értékeknél ezek a különbségek már nem mutatkoznak meg: sem a lágyítás hatása, sem pedig a kémiai összetételi eltérések. A 8. ábra diagramjaiban szereplő szaggatott vonalak az adott ötvözet lágy állapotára vonatkozóan előírt mechanikai jellemzők értékeit mutatják, melyek alapján mindhárom kémiai összetételi változat eléri, sőt meg is haladja a kívánt értékeket.

A mechanikai vizsgálatok mellett szemcseszerkezet-vizsgálatot is végeztünk. A metallográfiai felvételek mutatják a közbenső lágyítás nélküli (9. ábra) és a közbensőleg lágyított (10. ábra), már a végső vastagságra hengerelt minták szemcseszerkezetét az egyes kémiai összetételű min-

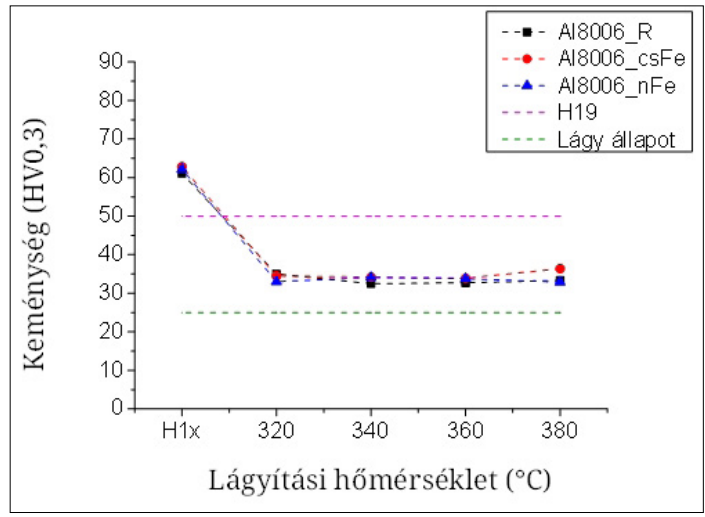

5. ábra. A közbenső lágyítás hatása az alakított minták keménységére

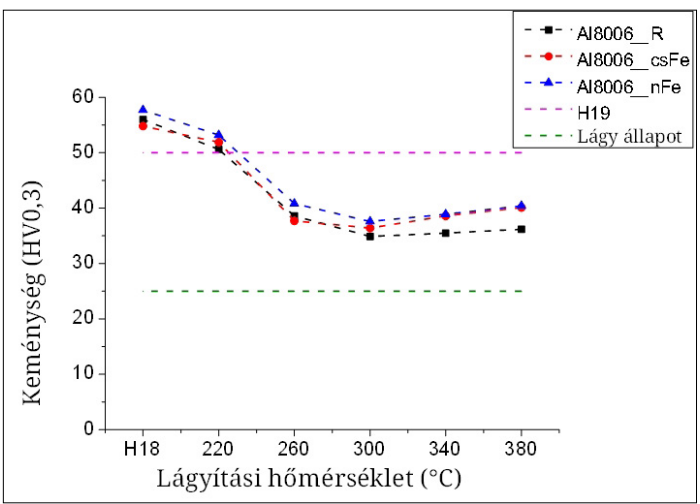

6. ábra. A véglágyítás hatása a közbenső lágyított minták keménységére

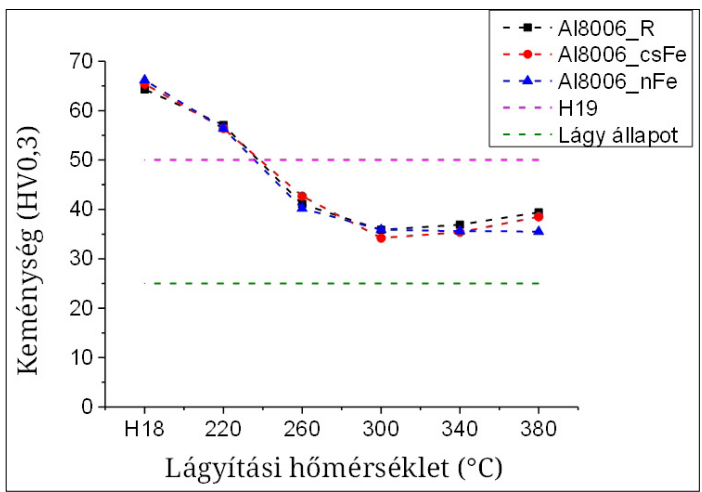

7. ábra. A véglágyítás hatása az alakított minták keménységértékeire

tákra. Az egyes összetételeknél a közbenső lágyítás hatását elemezve, a szemcseméret - az ASTM E112 szabvány szerint meghatározva - az R jelü minta esetén $(G=6,5-7)$ lényegesen nagyobb, de a csökkentett ( $G=7,5-8)$ és növelt $(G=8-8,5)$ vastartalmú ötvözetek esetén ez a jelentős különbség 

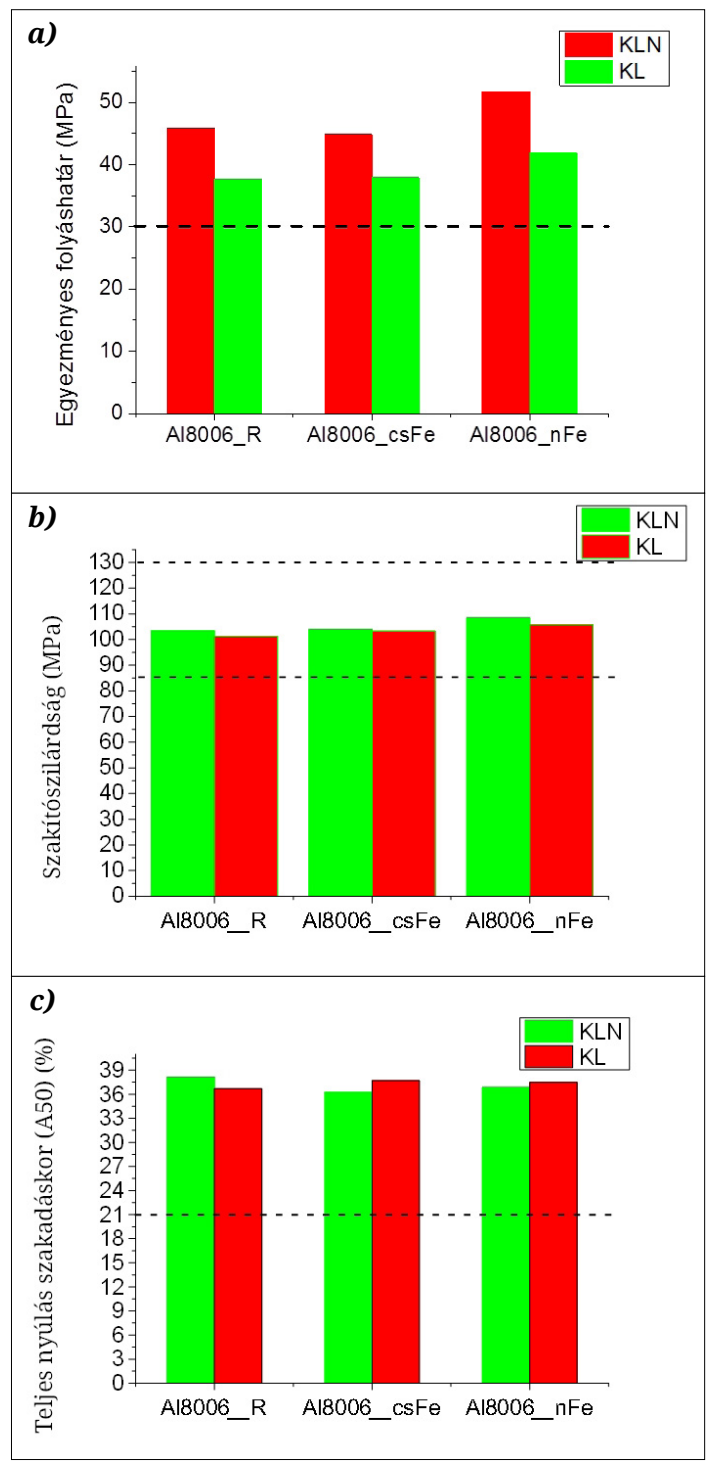

8. ábra. A kémiai összetétel és a közbenső lágyítás hatása a mechanikai jellemzőkre

a) Terhelt állapotban mért egyezményes fo-

lyáshatár (MPa)

b) Szakítószilárdság (MPa)

c) Százalékos szakadási megnyúlás, A50 (\%)

már nem figyelhető meg (9. ábra). Meg kell jegyezni, hogy itt is van szemcseméret-növekedés, de nem olyan nagymértékü, mint a referenciaanyagnál. A kémiai összetétel hatását tekintve a közbenső lágyítás nélküli mintáknál nem szembetűnő az eltérés. Ennél nagyobb különbség és sokkal finomabb szemcseszerkezet figyelhető meg a közbenső lágyított mintáknál, ahol a vastartalom változtatása, tehát a Fe/Mn arány változtatása,
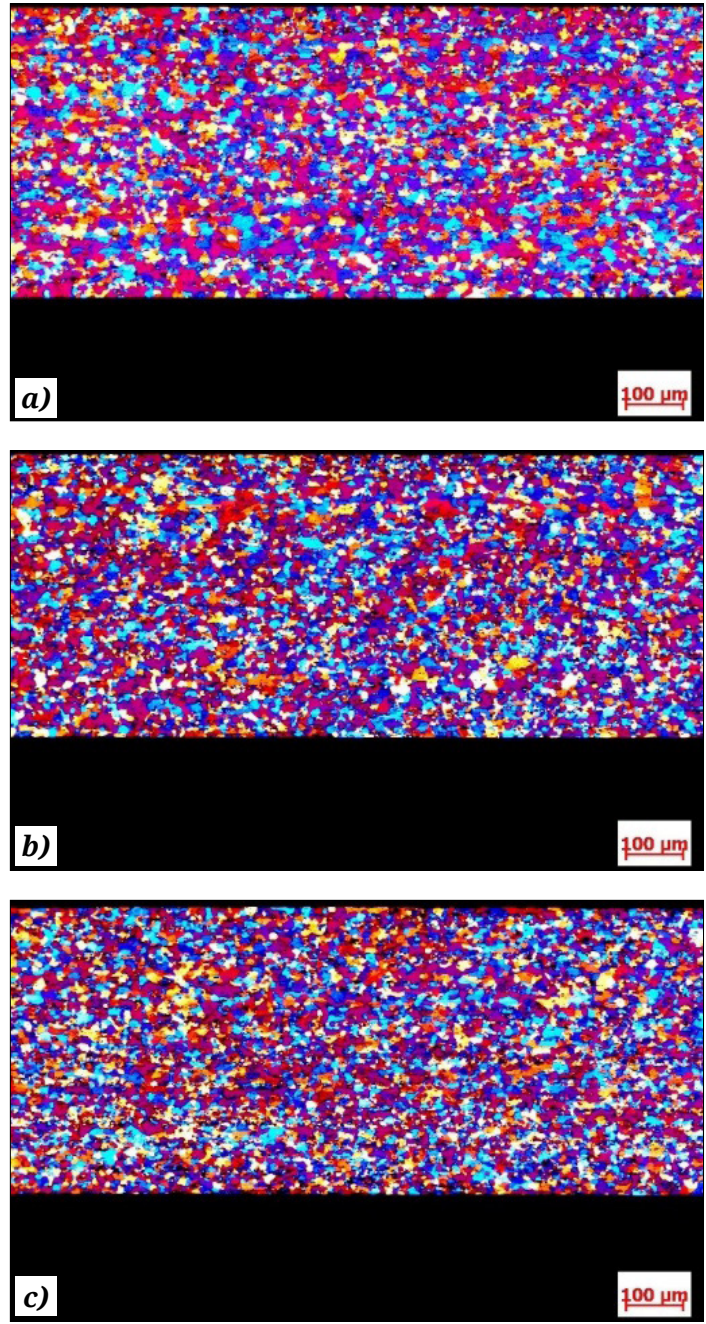

9. ábra. A szemcseszerkezet alakulása közbenső lágyitás nélkül

a) referenciaanyag

b) csökkentett vastartalmú ötvözet

c) növelt vastartalmú ötvözet

növelése és csökkentése egyaránt jelentős szemcsefinomodást okoz, azaz az R mintánál G = 6-6,5, a csFe mintánál $\mathrm{G}=6,5-7$, míg az nFe mintánál pedig $\mathrm{G}=7-7,5$, ami arra vezethető vissza, hogy a primer fázisszerkezet is változott (10. ábra).

\section{Következtetések}

Kutatómunkánk során az EN AW-8006 ötvözetet vizsgáltuk, oly módon, hogy három kémiai összetételi változatot állítottunk elő, és ezeken végrehajtottuk a homogenizálást, a meleghengerlést, a hideghengerlést és a minták egyik felénél a közbenső lágyítást, továbbá minden esetben a 

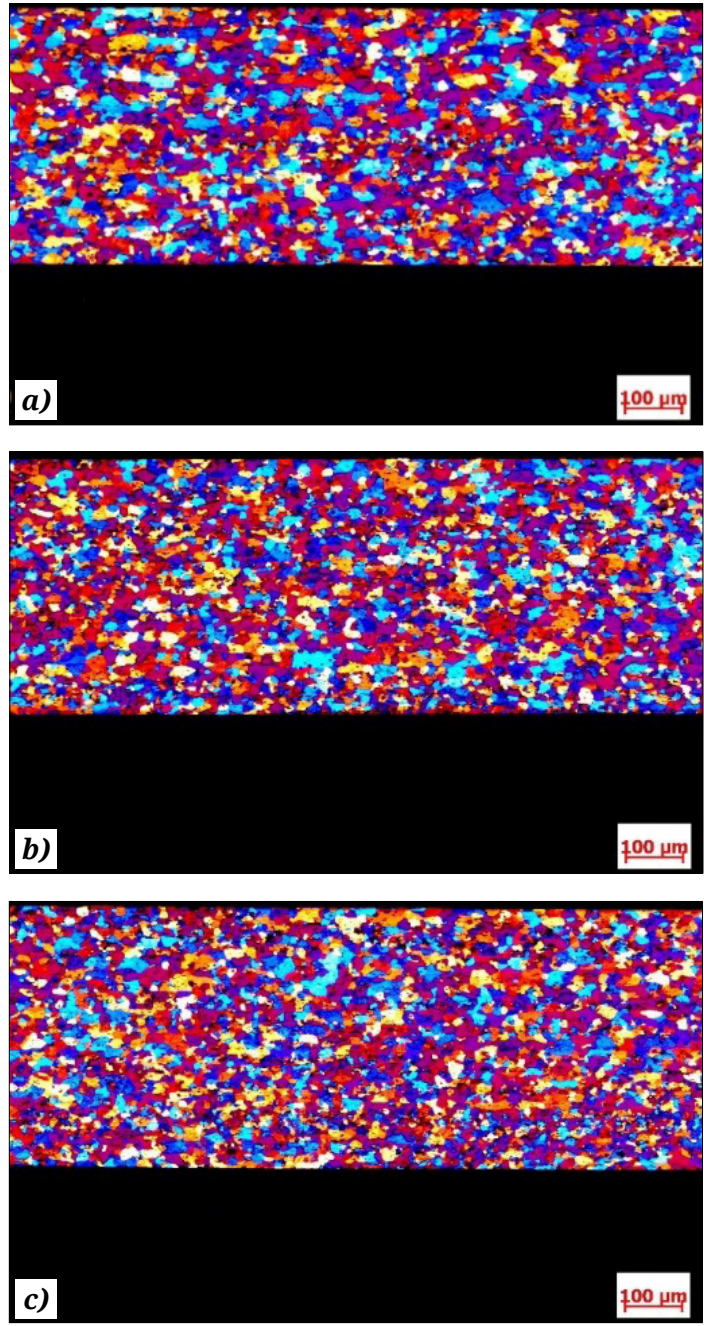

10. ábra. A szemcseszerkezet alakulása közbenső lágyítás alkalmazásakor

a) referenciaanyag

b) csökkentett vastartalmú ötvözet

c) növelt vastartalmú ötvözet

végső lágyítást. A különböző kémiai összetételű, valamint gyártástechnológiájú mintákon elvégzett szakítóvizsgálat, keménységmérés és szövetszerkezet-vizsgálat eredményei alapján az alábbi megállapításokat tehetjük:

1. A kémiai összetételi eltérések érdemi különbségeket csak a folyáshatár értékeiben mutatnak: a növelt vastartalommal $50 \mathrm{MPa}$ feletti egyezményes folyáshatár érhető el, közbenső lágyítás nélkül. Nem mutatható ki jelentősebb különbség sem a szakítószilárdság, sem pedig a százalékos szakadási megnyúlás értékeknél a kémiai összetétel változtatásával, illetve a közbenső lágyítás alkalmazásával.

2. A növelt, illetve a csökkentett vastartalom, tehát a $\mathrm{Fe} / \mathrm{Mn}$ arány változtatása hatással van a közbensőleg lágyított, majd végsőleg lágyított minták szemcseszerkezetére: finomabb, kisebb szemcseméretű szerkezetet hozhat létre.

\section{Köszönetnyilvánítás}

A szerzők ezúton mondanak köszönetet a GINOP2.2.1-15-2016-00018 számú „Új, piacképes hengerelt alumíniumtermékek technológiájának fejlesztése, a müszaki anyagtudomány legújabb eredményei alapján a piacvezető hazai iparvállalat, az ARCONIC-Köfém Kft és kiemelkedő hazai felsőoktatási K+F intézmények együttműködésében” című, továbbá az EFOP-3.6.1-16-2016-00003 számú, „K+F+I folyamatok hosszú távú megerősítése a Dunaújvárosi Egyetemen” című projektnek, valamint a EFOP-3.6.216-2017-00016 Autonóm járművek dinamikája és irányítása az automatizált közlekedési rendszerek követelményeinek szinergiájában című projektnek a kísérletek kivitelezhetőségéért. A projekt az Európai Unió támogatásával, az Európai Szociális Alap társfinanszírozásával valósult meg.

\section{Szakirodalmi hivatkozások}

[1] Moldovan P., Popescu G., Miculescu F.: Microscopic study regarding the microstructure evolution of the 8006 alloy in the plastic deformation process. Journal of Materials Processing Technology, 153154. (2004) 408-415.

https://doi.org/10.1016/j.jmatprotec.2004.04.345

[2] Englera O., Laptyeva G., Wang N.: Impact of homogenization on microchemistry and recrystallization of the Al-Fe-Mn alloy AA 8006. Materials Characterization, 79. (2013) 60-75.

https://doi.org/10.1016/j.matchar.2013.02.012

[3] Warmuzek M., Gazda A., Sieniawski J.: Processes of the formation of the $\mathrm{Fe}(\mathrm{Mn})$-bearing intermetallic phases in the Al-Fe-(Mn)-Si alloys. Advances in Materials Science, 4/2(4). (2003). 81-91. bwmeta1. element.baztech-article-BPG5-0015-0041

[4] Lentz M., Laptyeva G., Enger, O.: Characterization of second-phase particles in two aluminium foil alloys. Journal of Alloys and Compounds, 660. (2016) 276-288.

https://doi.org/10.1016/j.jallcom.2015.11.111

[5] Mundson D.: A clarification of the phases occurring in aluminium-rich aluminium-iron-silicon alloys, with particular reference the ternary phase $\alpha$-AlFeSi. Journal of the Institute of Metals, 95. (1967) 217-219.

[6] Keles O., Dundar M.: Aluminum foil: Its typical quality problems and their causes. Journal of Materials Processing Technology, 186. (2007) 125-137. https://doi.org/10.1016/j.jmatprotec.2006.12.027 